\title{
Psychological analysis of novel "Amba” by Lakme Pamuntjak
}

\author{
Adernarsy Avereus Rahman*) \\ Universitas Sebelas Maret \\ *) Correspondences author: Jalan Ir. Sutarmi No. 36A, Jebres, Surakarta 57126; Indonesia \\ e-mail: Adenary.avereus@gmail.com
}

\begin{abstract}
Literary work is the result of creative writing containing aesthetic values and the values of life conveyed through the meanings of the story. Narrating a story of literary works involves the roles' of the characters as the main figures that is consistent with the story and a psychological analysis of literary. The method used in this research was descriptive qualitative method. The data sources used were documents such as the review of the Novel amba. Data collection was done by using documentation and interviews. The results of this research are as follows: (1) dispositive key figures were illustrated by using the method of standpoint. (2) id aspect of the characters in the novel of Amba comes from life and death instincts as the form of survival or fulfilling the needs. (3) aspects of ego that exists in figures Novel amba are served as a means of meeting the needs and as a determinant in deciding any actions to take in response to the problems that occur within the characters. (4) aspects of the superego is depicted through the picture of them obeying the rules that exist in the society.
\end{abstract}

Key Words: psychology; novel Amba; id; ego; superego.

Article History: Received: 15/10/2017; Revised: 18/11/2017; Accepted: 27/11/2017; Published: 20/12/2017

How to Cite (MLA 7 ${ }^{\text {th }}$ ): Rahman, Adernarsy Avereus. "Psychological analysis of novel "Amba" by Lakme Pamuntjak." Hortatori Jurnal Pendidikan Bahasa dan Sastra Indonesia 1.2 (2017): 131-139. Print/Online. Copyrights Holder: Rahman, Adernarsy Avereus. First Publication: Hortatori Jurnal Pendidikan Bahasa dan Sastra Indonesia (2017).

This work is licensed under a Creative Commons Attribution-ShareAlike 4.0 International License.

\section{Pendahuluan}

Novel Amba karya Laksmi Pamuntjak diterbitkan pertama kali September 2012 oleh Gramedia Pustaka Utama. Novel ini terus mendapat pembaruan, cetakan kelimanya Juni 2015 sehingga mencapai 577 halaman. Laksmi Pamuntjak merupakan penulis generasi tahun 2000 yang mempunyai ciri khas tersendiri. Karya angkatan ini mempunyai ciri khas yaitu bertema sosial politik, romatik, gender, religi, dan feminisme. Karya sastra Angkatan 2000 menunjukan adanya kritikan baik dari segi sosial, budaya, politik, atau lingkungan dan kritikan itu disajikan lebih keras.

Selain itu mereka angkatan ini mulai berani memunculkan karya sastra yang cenderung berbau kasar (vulgar) dan mengadopsi pergaulan bebas. Kelebihan karya sastra pada angkatan ini yaitu: a) Pencerminan sebagai karya reformasi (perubahan) di mana terjadi revolusi, b) Penggunaan tema yang beragam, c) Kekuatan narasi yang baik, d) Banyaknya muncul karya sastra pembangun jiwa, d) Kejadian menarik yang inspiratif banyak digunakan penggarang dalam menuliskan karyanya.

Ciri khas dan kelebihan karya sastra angkatan 2000 ini terdapat pada novel Amba. Judul novel didasari oleh cerita Amba, salah satu tokoh pewayangan dalam Mahabharata (Koran Tempo, 14-15:2016). Novel ini berlatarbelakang sejarah tahun 1965 yang memasukkan unsur Mahabharata sebagai kerangka cerita yang ditulis secara modern. Cerita yang bernaratif corak realisme dan eksistensialisme ini mengambil latar belakang tempat-tempat yang menjadikan sejarah seperti rumah sakit Waeapo dan Universitas Res Publica. Bahasanya yang lugas serta pemakaian kata-kata yang puitis memudahkan pembaca untuk 
memahami kisahnya. Novel ini memberikan pengetahuan tentang sejarah, budaya, magis, estetika dan didukung referensi serta hasil riset yang luas serta dan teliti.

Kisah sejarah dalam novel Amba selain sebagai pengetahuan tentang kejadian 1965, juga ingin mengisahkan sisi lain kisah korban-korban yang jarang didengar. Mengangkat kisah tahun 1965, bukan berarti novel ini mengoreksi sejarah, tetapi sebagai pengetahuan tentang sejarah. Untuk memahami sejarah tidak berpandang dalam satu sisi saja, dibutuhkan pandangan yang beragam untuk memahaminya sehingga pengetahuan yang didapat tidak setengah-tengah. Oleh karena itu, kisah 1965 dikupas lagi dari sisi yang berbeda dalam novel ini.

Tokoh-tokoh dalam novel ini mengambil kisah Mahabharata yaitu Amba, Bhisma, dan Salwa. Bhisma seseorang yang dicintai Amba, seorang tapol di Pulau Buru yang tidak pernah kembali kepadanya. Cerita diawali kisah anak dari seorang guru di sebuah kota kecil Jawa Tengah, dibesarkan di Kadipura. Ia tumbuh dalam keluarga pembaca kitab-kitab tua. Setelah beranjak dewasa dia pergi ke Jogja untuk mempelajari banyak hal. Banyak kejadian serta peristiwa yang dialami Amba ketika di Yogja, yang saat itu ia bertunangan dengan Salwa, laki-laki yang penuh wibawa dan harga diri. Setelah sekian lama menjalin hubungan dengan Salwa, Amba merasakan kejenuhan dalam hubungannya. Kejenuhan bertambah dengan suasana kota Jogja yang tidak lagi memberikan semangat. Kemudian, dia mencoba melamar pekerjaan sebagai penerjemah rumah sakit di Kediri.

Kediri merupakan kota yang tidak aman pada saat itu. Banyak nasihat yang terima untuk tidak pergi ke kota Kediri, tapi dia memberanikan diri untuk menetap sementara di kota tersebut. Selain untuk mencari pengalaman baru, juga melarikan diri dari tunangannya. Setelah itu, dia bertemu Bhisma sosok laki-laki yang dikaguminya, mulai perawakan hingga kecerdasannya. Perjalanan cinta Amba yang penuh lika liku, di sisi lain Amba telah mengkhianati cinta Salwa yang yang tulus. Gejolak batin yang dialami Amba itu menjadi sangat rumit dan membebani perasaannya. Perjalanan cinta yang yang rumit ini semakin terlihat ketika Amba dan Bhisma harus terpisah oleh peristiwa tragis yang memisahkan mereka.

Kabar tentang Bhisma tidak terdengar lagi, Amba memulai kehidupan baru dengan Adalhard bersama anak hubungannya dengan Bhisma, Srikandi atau biasa dipanggil Siri. Tidak lama kemudian, Adalhard meninggal karena kanker. Tidak selang waktu yang lama, seseorang mengkabarkan tentang Bhisma yang berada Pulau Buru. Amba memutuskan untuk mengunjungi pulau tersebut bersama Zulfikar. Setelah terbang dari Jakarta menuju Ambon, lantas mengambil feri ekspres menuju Pulau Buru.

Berdasarkan uraian tersebut, penulis tertarik mengkaji psikologi tentang psikis tokoh dalam novel Amba karya Laksmi Pamuntjak. Hal ini didasari oleh banyaknya peristiwa menggambarkan kondisi psikis para tokohnya. Berbagai konflik yang muncul dalam cerita berasal kondisi-kondisi psikis tersebut. Untuk memahami novel ini secara komprehensif perlu pemahaman hal-hal yang bersifat psikologi tersebut.

Tulisan ini mencoba menganalisis psikologi tokoh-tokoh utama dalam novel Amba karya Lakmi Pamuncak. Tokoh-tokoh tersebut diantaranya Amba Kinanti, Bhima Rashad, dan Salwani Munir. Selain dominan dan banyak dibicarakan, kehadiran dalam setiap konflik sangat penting. Teori yang digunakan untuk analisis psikologi dari Sigmud Freud yang mencakup psikis id (das es), ego (das ich), dan superego (das ueber ich).

\section{Metode}

Metode yang digunakan dalam penelitian ini adalah metode kualitatif. Sebagaimana sifat dari penelitian kualitatif yaitu mencari makna dari suatu fakta atau fenomena, maka kesungguhan seorang peneliti dituntut ketika melakukan suatu observasi atau pengamatan di lapangan.

Data dalam penelitian ini berupa primer dan sekunder. Data primer adalah telaah dokumen novel Amba karya Laksmi Pamuntjak cetakan kelima Juni 2015 yang diterbitkan oleh PT Gramedia Pustaka Utama, yang berupa kata, kalimat dalam bentuk ungkapan, dan dialog antar tokoh yang menunjukan aspek psikis id, ego, dan superego.

Adapun data sekunder dalam tulisan ini adalah sumber yang berhubungan dengan permasalah dalam objek tulisan. Hampir semua jenis bahan kepustakaan (buku, artikel, atau esai) dikelompokkan dalam data sekunder. Sumber data dalam penelitian ini adalah karya tulis ilmiah, buku-buku, dan artikel yang berkenaan dengan objek penelitian yaknti novel Amba yang menjadi sumber primer. 


\section{Hasil dan Diskusi}

\section{Aspek Psikis Id Tokoh-Tokoh Novel Amba}

\section{1) Amba Kinanti}

Aspek psikis id Amba dalam novel ini sangat kuat. Cara kerja id berhubungan dengan prinsip kesenangan. Aspek psikis id yang dialami Amba dimulai saat berkenalan dengan Bhisma, dokter dari Jerman yang bekerja di rumah sakit Kediri. Sejak berkenalan, timbul gairah sehingga ia tidak bisa mengkontrolnya. Amba mengalami kondisi psikiologi untuk mengikuti nalurinya, "Hati Amba gemuruh. Dan sekarang Bhisma duduk disebelahnya. Ia tak sanggup mengangkat kepalanya. Ia lirik kuku tangan Bhisma, yang digigiti sampai habis. Ada bercak darah pada jaket dokternya yang putih. Detail-detail tak elok yang membuat laki-laki itu semakin elok di matanya (Pamuntjak, 2015:217).”

Id yang semakin kuat membuat Amba menginginkan lebih dari sekadar ciuman. Ada gairah ketika melihat Bhisma, Amba berharap sebuah hubungan tidak hanya dengan makan bersama atau pergi bersama. Tapi, dia menginginkan hal yang lebih, seperti cerita dalam kitab-kitab yang dibacanya,"Malam itu Amba membiarkan Bhisma tinggal di kamarnya, dan ketika kemudian Bhisma membaringkannya di ranjang itu, ia menangkupnya dengan mulut, tangannya seluruh tubuhnya. Mereka tetap begitu sampai fajar (Pamuntjak, 2015:226)."

Amba tidak memiliki kekhawatiran ketika Bhisma bermalam di kamarnya. Dia menginyakan tindakan Bhisma, dia berpikiran inilah yang diinginak selama ini, jadi tak ada satupun yang mampu menahanya. Di sinilah dorongan seksualitas Bhisma muncul, apalagi Amba sendiri tak menolaknya. Intensitas pertemuannya dengan Bhisma membuat Amba merasa benar-benar jatuh cinta meskipun ia bertunangan dengan Salwa. Tetapi Amba sadar bahwa sosok laki-laki seperti Bhisma yang ia inginkan. Ia sendiri menyadari tindakannya tersebut, tetapi dia tetap seorang manusia yang membutuhkan seksualitas sebagai pemenuhan nalurinya. Tak jauh berbeda dengan Amba, Bhisma sendiri juga merasakan hal yang sama. Dorongan id yang tidak bisa dikuasai membuat gairah keduanya ini meningkat, "Lalu, karena di luar tak ada bulan, hanya dan katak di rerumputan, ia kembali rileks. Tubuh dan aroma mereka tertaut, seakan mereka dilahirkan untuk berpasangan. Inikah yang dilakukan orang menikah? Pikir Amba, setengah mabuk (Pamuntjak, 2015:248)."

Berdasarkan penjelasan di atas dapat disintesiskan bahwa aspek psikis id yang dimiliki oleh Amba. Amba merasakan jatuh cinta kepada Bhisma, seakan-akan tak mau berpisah dengannya. Oleh karena itu, Amba tidak mempunyai keraguan menyerahkan yang dimilikinya, termasuk keperawanannya. Bhisma baru dikenalnya satu bulan, tetapi tidak perlu berlama-lama bagi mereka berdua untuk mengenal satu sama lain. Dia melakukan hal tersebut karena tuntutan naluri seksualitasnya. Jadi, id yang dimiliki Amba ini terpenuhi.

\section{2) Bhisma Rashad}

Aspek psikis id yang ada dalam Bhisma terlihat ketika ia jatuh cinta kepada Amba. Bhisma merasa ada gairah dalam Amba. Gairah asalnya dari id seksualitasnya. Aspek psikis id yang ada dalam Bhisma ingin terpenuhi. Bhisma sendiri tak ragu-ragu dalam mencari pemenuhan kebutuhan naluri seksualitasnya. Ketika pemenuhan kebutuhan aspek id ini terpenuhi, rasa senang yang dirasakan Bhisma. Oleh karena itu, kondisi psikis yang ditunjukan Bhisma adalah rasa senang dan cinta yang dalam kepada Amba. Ini terlihat dalam kutipan berikut ini :

Bhisma memegang tangannya erat-erat, dan dengan pelan sekali mengangkatnya ke bibir.

Amba ingin mengatakan, aku tidak bemimpi aku tidak..tapi terhenti karena ia merasakan mulut Bhisma melekat pada mulutnya: basah yang manis, besi, binatang, begitu sedih, begitu panjang, begitu biru. (Pamuntjak, 2015:98-222)

Sikap itu merupakan aspek psikis $i d$. Kondisi psikis timbul karena perasaan cinta pada Amba sehingga memegang tangan Amba dan mulai melakukan hal lebih. Kondisi psikis adalah senang ketika Bhisma mampu memenuhi kebutuhan seksualitasnya. Perasaan senang atau puas yang diperlihatkan oleh Bhisma timbul dari id yang ada dalam dirinya. Perasaan tenang dalam dirinya ketika ia mencintai Amba, "Lalu Bhisma menatapnya dalam-dalam. "perasaan yang seperti itu," kataya sambil mengelus rambut Amba, "datang lagi kepadaku ketika pertama kali bertemu, seminggu lalu. Sebelum kamu masuk ke dalam hidupku, aku merasa dalam suaka yang tenang yang aneh, yang dalam (Pamuntjak, 2015:250).” 
Kondisi psikis id timbul berdasarkan naluri kebutuhan akan kasih sayang. Ada ketenangan bersama Amba, bahwa cinta yang dimilikinya membawanya dalam ketenangan dan kesenangan. Bhisma tak terusik dengan kondisi Amba yang saat itu tunangan orang lain. Bhisma hanya berpikiran bahwa saat ini Amba ada bersamanya. Bhisma menunjukan sikap tak peduli dengan cerita Amba, yaitu dengan mencumbu kekasihnya itu, "Dan begitu saja momentum lewat, karena Bhisma balik menciuminya kembali, seperti seseorang yang tak mau diusik oleh kenyataan. Dan seperti sehimpun putri malu, tubuh Amba luluh sekali lagi pada tiap sentuhannya. Kata-kata akan terasa berlebih (Pamuntjak, 2015:269)."

Aspek psikis id Bhisma berjalan atas dasar rasa senang yang diperolehnya, tanpa memikirnya norma atau moralitas dari kenyataan yang dihadapinya. Dia merasakan bahwa yang terjadi antara dirinya dan Amba cukup dijalani saja, tanpa harus memikirkanya. Bhisma melakukannya atas dorongan aspek psikis $i d$ berdasarkan kebutuhan atas cinta yang berlanjut pada kebutuhan seksualitasnya yang bekerja atas dasar kenikmatan. Bhisma tidak terlalu memikirkan dampaknya. Berdasarkan aspek psikis $i d$, hal ini diakukan atas dasar cinta dan kebutuhan seksualitasnya. Rasa cinta dan libido merupakan naluri yang memang sudah ada sejak dulu. Sama halnya dengan gairahnya ketika bersama Amba.

\section{3) Salwani Munir}

Aspek psikis id yang dimiliki oleh Salwa merupakan timbul berdasarkan naluri kehidupan. Kebutuhan kehidupan tidak hanya makan, minum tapi, kebutuhan akan cinta dan kasih sayang serta seksualitas. Kondisi tersebut terlihat ketika Salwa bertemu dengan perempuan berkebaya, ada perasaan senang ketika Salwa bertemu dengannya. Perasaan senang yang dirasakan Salwa merupakan kondisi psikis timbul dari $i d$. Salwa suka bertemu dengan lawan jenisnya yang lebih berumur. Rasa suka yang dirasakan Salwa ini timbul dari nalurinya, "Salwa semakin tak berani bertanya soal moralitas ketika ia sadar merasa senang beberapa kali bertemu dengan perempuan berkebaya dan berwajah merah jambu itu (Pamuntjak, 2015:115)".

Aspek psikis id Salwa juga memperlihatkan keinginanya untuk memiliki wanita seperti ibunya. Cintanya terhadap ibunya yang besar membuat Salwa merindukan sosok perempuan yang mirip ibunya. Salwa merasakan senang bila ada wanita seperti ibunya "Ia merindukan perempuan yang kuat dan berpendirian seperti ibunya, perempuan yang tahu apa yang diingkannya, tapi yang juga tidak agresif (Pamuntjak, 2015:115)."

Perasaan Salwa melihat sosok wanita seperti ibunya merupakan kesenangan tersendiri. Apa yang dirasakan Salwa ini merupakan aspek psikis berdasarkan $i d$. Id berlaku pada seluruh tingkat kesadaran dan tidak diatur oleh pertimbangan waktu, tempat, dan logika karena $i d$ hanya berprinsip pada rasa kesenangan saja. Aspek psikis id Salwa nampak ketika mulai beranjak dewasa, tepatnya ia mulai kuliah dan bekerja di UGM. Perasaan suka terhadap lawan jenis mulai dirasakan, ketika ia jatuh cinta kepada rekan kerjanya. Meskipun konsep cinta bagi Salwa adalah menjaga kehormatan pasangannya.

Aspek psikis id yang dimiliki Salwa ini sangatlah sederhana, dia memang merasakan cinta dan kebagiaan dalam menjalani suatu hubungan dengan lawan jenisnya. Gairah Salwa hanya sampai tahap ciuman di pipi kekasihnya. Salwa beranggapan itulah yang seharusnya dilakukan ketika dua pasangan sedang jatuh cinta, sebatas gairah sewajarnya. Salwa hanya mengajaknya makan dan nonton.

Aspek id dalam diri Salwa ini masih bisa dikendalikan, terlihat ketika Salwa bersama Amba, dia mencintai wanita itu dengan penuh penghargaan dan penghormatan. Implus akan menimbulkan dorongan-dorongan untuk melakukan pemenuhan atas kebutuhannya ini masih terkontrol dalam diri Salwa.

\section{Aspek Psikis Ego Tokoh-Tokoh Novel Amba}

\section{1) Amba Kinanti}

Aspek psikis ego Amba ini terlihat ketika Bhisma mengajaknya untuk bertemu dengan temantemannya. Saat itu Bhisma tidak memperkenalkan Amba sebagai kekasihnya, hanya dengan menyebut namanya. Aspek psikis ego memang bekerja atas dasar realita, Amba merasakan bahwa realita yang dipilihnya adalah diam meskipun Bhisma tidak memperkenalkannya sebagai pacar Bhisma. Sikapnya yang diam merupakan cara ego untuk mencari cara untuk memenuhi kebutuhan-kebutuhan yang sesuai dengan realita. Amba sadar dalam akan sikapnya yang diam dan tidak melakukan penyangkalan, karena tindakan yang dilakukan atas dasar kemauannya berasal dari ego. Amba merasakan ketidakpuasan dengan perbuatan Bhisma, ini terlihat di kutipan berikut ini : 
Dada Amba ngilu, karena Bhisma tak menjelaskan hubungan mereka. Ia bukan pacarnya. Bukan pula temannya, tapi ia tahu kedua istilah itu sama-sama tak tepat, sama-sama tak berlaku, dan oleh karena itu Bhisma tidak salah. Amba adalah pacarnya karena ia orang lain (meskipun orang lain itu belum pernah menyetubuinya) ia juga bukan teman karena mereka telah bersutubuh (sebab teman tak saling bersetubuh) (Pamuntjak, 2015:288).

Amba dan Bhisma mengalami kisah cinta yang indah dan penuh gairah. Namun, kisah cinta mereka tidak berjalan sesuai keinginan mereka. Setelah kejadian gerakan 30 September di Yogyakarta, Amba dan Bhisma terpisah untuk selama-lamanya.

Aspek psikis ego terlihat dalam diri Amba ketika memutuskan untuk tidak mencari Bhisma. Keputusan yang diambil berdasarkan ego mencari jalan untuk memenuhi kebutuhan yang dibutuhkan Amba. Proses realistis bentuk pemikiran Amba didasari oleh realita yang ada, sehingga dari pemikiran yang realistis tersebut diwujudkan dengan tindakan. Dampak yang timbul dari ego tersebut ialah emosi, kecewa, marah, dan putus asa. Kondisi psikologis marah, kecewa, dan putus asa terjadi karena ego tidak bisa terpenuhi, "Aku enggak akan mencari bhisma, suara amba mantap. Semuanya sudah selesai. Antara aku dan dia nggak ada apa-apa lagi. Buktinya dia nggak mencari aku, jangan-jangan dia memang nggak berniat mencari aku. Aku ingin secepatnya ke Jakarta. Aku enggak merasa aman di sini (Pamuntjak, 2015:354)."

Ego berperan dalam aspek psikologis Amba, ketika ia memutuskan tidak mencari Bhisma. Ego pada dasarnya diatur oleh prinsip realitas. Amba sadar bahwa realitas yang ia hadapi sekarang bahwa Bhisma hilang dan tidak kembali padanya, jadi ia memutuskan berdasarkan realitas yang ada untuk tidak mencari bhisma. Ia memilih Jakarta sebagai awal kehidupan yang baru. Dia memilih Adalhard sebagai sosok laki-laki yang mau menerima kondisinya. Akhirnya, perjalanan pernikahannya juga tak berlangsung lama, Adalhard meninggal karena sakit yang dideritanya. Selama pernikahannya dengan Adalhard, ia masih belum berdamai dengan masa lalunya. Dia masih ingin tahu kondisi Bhisma yang sebenarnya. Oleh karena itu, sepeninggalan Adalhard, ia memutuskan untuk mencari Bhisma di Pulau Buru. Setelah dia menerima pesan Bahwa Bhisma telah meninggal.

Ego yang tersimpan dan direndamnya selama ini. Puncaknya aspek psikis ego yang dimiliki menuntut untuk membuat keputusan. Akhirnya, ia mencari Bhisma lagi baik hidup atau mati. Agar kehidupan yang dijalaninya tidak terganggu dengan masa lalunya. Dia melakukan ini sebagai pemenuhan atas yang telah ingin dibutuhkan yaitu, berdamai dengan masa lalunya. Amba melakukan hal tersebut agar dia tak terikat lagi dengan masa lalunya, sehingga yang dirasakan bisa menjadi tenang. Kondisi psikologis dari aspek ego ini menimbulkan rasa ingin tahu yang besar terhadap yang butuhkannya.

Berdasarkan hal tersebut disimpulkan, bahwa aspek psikis ego tokoh Amba terlihat dengan mengontrol jalan atau cara yang ditempuh untuk memilih kebutuhan yang dapat dipenuhi. Serta cara-cara memenuhinya dan memilih objek-objek yang dapat memenuhi kebutuhannya. Seperti Amba mengambil keputusan untuk tidak mencari Bhisma, Ego berfungsi sebagai sarana dalam memenuhi atau tidak memenuhi kebutuhan atas dorongan-doronga dari $i d$, yang dilakukan ego merupakan berdasarkan prinsip realitas. Ego juga bekerja sebagai sarana memutuskan pilihan, yang sesuai dengan prinsip realitas sebagai dampak dari ego yang tidak terpenuhi ialah rasa marah, kecewa, dan putus asa.

\section{2) Bhisma Rashad}

Aspek psikis ego yang dimiliki Bhisma merupakan kondisi psikis ego timbul dari rasa kenyakinannya untuk membahagiakan Amba. Dia yakin dengan cinta dan kemampuan untuk membahagiakan Amba. Bhisma menjadikan alasan ini untuk menyakinkan Amba "bahwa kita bisa hidup bersama dan bahagia apalagi dengan rasa cinta yang kita miliki saat ini". Bhisma menjelaskan bahwa dia tak ada keraguan untuk tetap bersama Amba. Meskipun dia tahu bahwa Amba milik orang lain. Dia tak segan merebut dari Salwa karena ego menuntut untuk mencari pemenuhan atas kebutuhannya akan kasih sayang, "Bhisma tampak terkejut, ia mungkin melihat perubahan yang tidak bisa lengkap ia tangkap, dan ia pun berlutut, memegang kedua tangan Amba. "apa yang terjadi? Kenapa tiba-tiba begini? Aku kan sudah janji kita akan bersama (Pamuntjak, 2015:300).

Di sisi lain aspek psikis ego yang dirasakan Bhisma, memutuskan untuk melepas Amba. Ego yang dirasakan oleh Bhisma setelah melihat realitas yang ada, bahwa Bhisma tak bisa memberi kepastian dalam hubungannya. Di sisi lain, Bhisma masih mempunyai kewajiban untuk temannya Unarto jadi kondisi psikis egonya memutuskan Amba harus kembali ke Salwa tunangannya. Karena hanya dengan Salwa, Amba akan 
mendapat kebahagiaan. Ia merasa tak bisa membahagiakan Amba, karena ia masih mempunyai tanggung jawab untuk teman-temanya di CGMI. Ini terlihat dalam kutipan berikut ini :

Amba terdiam lama. Lalu bhisma mengatakan sesuatu yang tak diduganya, "aku tahu ini berat bagimu. Mungkin aku belum punya rencana. Dan selama CGMI masih terpecah, dan kawan-kawan Unarto masih jadi target. Aku akan harus berada disini. Kalau kamu merasa lebih aman untuk pergi, pergilah. Kamu belum menyadarinya sekarang, tapi Salwa akan menyelamatkanmu (Pamuntjak, 2015:320).

Perasaan Bhisma seakan dalam keadaan bimbang. Dia telah berjanji untuk membahagiakan Amba tapi di sisi lain dia juga masih mempunyai kewajiban untuk teman-temannya yang ada CGMI. Akhirnya, Bhisma membuat keputusan berdasarkan pengamatannya dalam hubungan cintanya dan kewajibannya. Dia memutuskan untuk melepas Amba untuk kembali ke Salwa. Karena target utamanya membantu temantemannya yang mengalami kesusahan. Ia seorang dokter yang berkewajiban mengobati pasien, dan ia akan dibutuhkan di mana saja selama ia ditempatkan. Inilah kondisi psikis ego Bhisma berdasarkan realitas yang ada. Kenyataannya, ia lebih mengutamakan untuk membantu teman-temannya dari pada hubungannya cintanya. Setelah mencoba berdamai dengan kenyataan kehidupan, Bhisma tetap tidak bisa melupakan Amba.

Bhisma tak lelah dalam berusaha menyakinkan Amba, bahwa setelah menghadiri pemakaman Unarto di Ureca akan mengajaknya untuk meninggalkan Yogya dan hidup bersama. Hidup bersama Amba merupakan yang diingkannya, ia telah jatuh hati dan menyerahkan hidupnya kepada Amba. Tidak ada yang bisa merubah keputusan tersebut meskipun Amba sudah bertungangan.

Berdasarkan aspek psikis ego, terkadang Bhisma dapat melihat kenyataan bahwa ia seorang dokter yang mempunyai tanggung jawab yang besar. Dia harus siap untuk membantu siapa saja yang membutuhkannya. Di lain pihak, hatinya telah terpaut dengan Amba, dia membutuhkan Amba. Bhisma telah menyerahkan hatinya beserta hidupnya. Kebimbangan yang dirasakan Bhisma ini merupakan ego yang belum bisa diputuskan tentang yang sebenarnya. Tapi ada keselarasan dalam egonya yang memutuskan untuk menyelesaikan masalahnya dan setelah itu hidup bersama Amba.

\section{3) Salwani Munir}

Aspek psikis ego yang ditampakkan Salwa ialah dengan mencari kebenaran atas kondisi Amba. Salwa datang kepada Bhisma dan menanyakan kejelasan hubungannya dengan Amba. Apa yang dilakukan Salwa bentuk dari mencari jalan serta objek untuk memenuhi kebutuhannya. Kebutuhannya akan kejelasan dan kejujuran Bhisma yang telah merebut Amba darinya. Cara yang dilakukan Salwa berasal dari tuntutan ego untuk memenuhi kebutuhannya, kebutuhan yang didasari oleh prinsip realitas. Dampak yang dihasilkan dari realita tersebut marah dan kecewa, mengetahui Amba menduakan cintanya. Ia tahu bahwa yang sedang terjadi bukan sekadar khayalan atau bahkan mimpi, inilah kenyataan yang seharusnya Salwa terima bahwa cinta yang tulus dan suci yang berikan kepada Amba telah dikhianati. Ini terlihat dalam kutipan berikut ini: "saudara mungkin tak habis pikir, bagaimana saya tahu," kata Salwa dengan tenang. "ketika sepasang manusia dimabuk cinta, mereka sering tak menyadari bahwa seluruh dunia bisa melihatnya. Aneh Salwa saudara tak mengetahuinya dengan pengalaman hidup saudara yang katanya luar biasa itu" (Pamuntjak, 2015:537).

Sikap yang tenang ia tunjukan ketika menemui Bhisma dalam penjara, alasan menemui Bhisma memintak kejelasan serta kejujuran tentang hubungannya dengan Amba. Meskipun bersikap tenang, Salwa tidak bisa menutupi amarah dan kecewanya. Salwa tahu bahwa cara yang ditempuhnya mengakibatkan sakit hati, dan tidak terima. Tetapi Salwa yakin dengan menemui Bhisma, rasa ingin tahunya segera terpenuhi. Di sisi lain Salwa menunjukan sikap wibawa dan penuh harga diri, meskipun tersakiti. Salwa beranggapan bahwa dia masih lebih terhormat dari pada Bhisma. Salwa mengetahui semua yang dilakukan Bhisma dan Amba dari kenalannya di rumah sakit itu.

Salwa merasa dia perlu mencari tahu tentang kondisi Amba, oleh karena itu dia menghubungi kepala rumah sakit dengan menyakan keberadaan Amba. Kepala rumah sakit itu menceritakan semua kejadian yang terjadi pada Bhisma dan Amba. Tindakan yang dilakukan Salwa merupakan dorongan egonya untuk mancari jalan, cara atau objek sebagai pemuasan kebutuhannya. Kebutuhan yang didasari oleh prinsip realitas membuat Salwa menerima risiko yang akan diperolehnya. Dampak dari realita yang didapat Salwa adalah amarah. Dia ingin tahu bahwa di mana tunangannya tersebut, tapi Bhisma sendiri benar-benar tak tahu di mana tunangan Salwa atau kekasihnya tersebut. Salwa benar-benar tidak tahan dengan yang dilihatnya. Ini terlihat pada kutipan berikut ini: 
Maaf, tapi saya tidak mau dengar masalahnya. Paling tidak bukan dari susut pandang saudara. Saya tahu masalah saya, dan itu sudah cukup. Masalah saya adalah bagaimana hidup dengan pengkhianatan, pengkhianatan orang yang paling saya kasihi dan percayai dalam hidup saya. Bagi saya tak ada luka yang lebih dalam. Dan sekarang semuanya sudah jelas, semuanya sudah berakhir. Mulai sekarang, dia adalah masalahmu. Saya tidak ingin, tidak bisa, tidak akan pernah menerimanya kembali (Pamuntjak, 2015:539).

Salwa tidak sempat mendengar cerita Bhisma, dia tidak peduli tentang yang terjadi diantara mereka berdua. Salwa harus hidup dengan menerima kenyataan yang pahit, bahwa dia telah dikhianati oleh kekasihnya. Amba yang ia cintai,dan kasihi dalam hidupnya. Aspek psikis ego yang ditunjukan oleh Salwa merupakan hasil dari prinsip realitas. Ego Salwa menunjukan tindakan menerima dengan semua yang terjadi. Baginya, harga diri dan kewibaan serta kesederhanaan dalam mencintai adalah sesuatu yang tidak bisa ditawar lagi. Ia benar-benar melepaskan Amba dan ia tidak mau menerima Amba lagi.

Aspek psikis ego yang ditunjukan oleh Salwa adalah kondisi menerima semua yang terjadi pada dirinya. Salwa menerima kenyataan kisah cinta dengan Amba berakhir dengan pengkhianatan. Dia juga harus menerima bahwa Amba telah meninggalkannya. Sikap itu merupakan wujud dari ego yang mengambil tindakan untuk menerima semua kenyataan hidup yang dialami, sebagai bentuk pemenuhan atas kebutuhan dan kepuasannya. Dampak yang ditimbulkan ialah amarah, kecewa, terkhianati atas cintanya yang tulus.

\section{Aspek Psikis Superego Tokoh-Tokoh Novel Amba 1) Amba Kinanti}

Aspek superego Amba menuntut keseimbangan hatinya dengan apa yang terjadi dalam hidupnya. Keseimbangan didapatnya dari renungan hatinya atau suara hatinya dari berbagai masalah yang datang dalam hidupnya. Oleh karena itu, dia merasa hati kecilnya memberikannya sebuah realitas baik secara moral, norma maupun pengendalian atas dirinya. Salah satunya kesadaran itu ialah bahwa manusia dianjurkan untuk menjaga sikap dan bicaranya. Meski tidak tercatat dalam aturan, tetapi menjadi aturan tak tertulis yang dipatuhi setiap mahluk hidup, "Mungkin itu sebabnya kita tidak diajari untuk mengumbar kata, karena begitu sesuatu diikrarkan, kita terikat, dan tak bisa menariknya kembali. Pada hari-hari aku semakin sadar, tak ada laku yang lebih kesatria dibanding menepati janji (Pamuntjak, 2015:356)."

Amba merasakan dampak dari ucapan yang diyakininya, bahwa Salwa memang bukan jodohnya, dan Bhismalah sosok laki-laki yang akan merebutnya dari Salwa. Bhisma juga yang membuatnya mengalami kepahitan hidup ini. Ia sadar seharusnya Amba tidak pernah mengumbar kenyakinanya tentang hidupnya, berdasarkan cerita asal dalam kitab-kitab yang dibacanya. Karena jika kata-kata tersebut terikat dengan dirinya maka cerita tersebut akan terjadinya padanya. Sebagai manusia harus bisa menjaga ucapan. Ada keseimbangan yang dirasakan oleh Amba ketika, ia menyadari yang telah terjadi pada dirinya. Membuat dirinya memutuskan untuk tidak merendahkan Salwa lagi atas kesetiaannya.

Berdasarkan aspek superego Amba, memperlihatkan adanya kesadaran diri tentang tingkah laku yang telah diperbuatnya. Amba sadar ada kalanya dalam kehidupan selalu menjaga perilaku dan bicara, agar nantinya tidak mendatangkan masalah. Kesadaran timbul dari hati kecilnya menuntunya untuk memaknai setiap kejadian dan peristiwa yang telah dilalui. Sebagai bentuk ajaran tentang tingkah laku hidup yang baik berdasarkan pandangan hidup. Dengan memahami perilaku yang baik atau buruk, akan berdampak kepada kehidupan sosial yang nantinya akan timbul kesimbangan dan harmonis.

\section{2) Bhisma Rashad}

Aspek psikis superego Bhisma memperlihatkan, bahwa sikapnya yang menghormati dan menghargai ibunya merupakan tindakannya yang positif. Ia sangat mengormati dan menghargai ibunya, karena ibunyalah sosok perempuan yang sangat mengerti dirinya. Ada tekad yang kuat dalam diri Bhisma, bahwa apapun yang terjadi pada dirinya dia akan selalu ingat ibunya. Bhisma beranggapan pelajaran hidup yang didapat merupakan pengalaman yang jarang sekali orang lain dapatkan dan untuk itu ia berterima kasih kepada ibunya. 
Pengalaman hidupnya yang banyak membuatnya sadar, tentang perilaku di mata masyarakat. Moralitas merupakan aspek kepribadian yang diperlukan seseorang dalam kehidupan sosial yang harmonis, adil, dan seimbang. Bhisma merasa kurang berkenan anggapan teman-teman dan sepupunya tentang moralitas. Moralitas menurutnya, tidak selalu tentang seks. Oleh karena itu, dengan keberaniannya Bhisma mencoba memberikan pembenaran tentang konsep tersebut: Sejak saat itu ia diam, juga ketika bertemu dengan teman-teman masa lalu atau sepupunya yang kerjanya bergunjing tentang wanita favorit Bung Karno yang terbaru. Suatu kali ia tak tahan dan memperotes, "kenapa moralitas selalu dihubungkan dengan seks? Kenapa kita nggak mempersoalkan hal-hal yang lain korupsi misalnya?’Pamuntjak (2015:233).

Berdasarkan aspek psikis superego, Bhisma memerlihatkan nilai moral. Bhisma mewujudkannya dengan melakukan tindakan yang positif. Seperti menghargai dan menghormat ibunya, selain itu ia juga menyatakan kebenaran tentang konsep moralitas kepada teman-temannya dan sepupunya. Aspek superego Bhisma timbul dari suara.

\section{3) Salwani Munir}

Aspek psikis superego dalam diri Salwa timbul karena ia tahu tentang artinya tanggung jawab sebuah keluarga. Perilaku baik dan santun ditunjukannya. Meski usianya muda, dia sudah mengenal arti tanggung jawab pada keluarga, dengan menyisihkan sedikit uang hasil kerjanya untuk ibunya. Baginya membalas budi ibunya merupakan tanda bakti seorang anak terhadap orangtuanya. Ini terlihat dalam kutipan berikut ini:

Tapi ia anak sulung, ia tahu sesuatu tentang tanggung jawab, tak ada yang membuatnya lebih puas ketimbang mengirim uang kekeluarganya. Setiap kali ibu ibu menulis surat terima kasih kepadanya, ia menyakinkan dirinya bahwa tak ada tanggung jawab yang lebih mulia ketimbang dengan membalas budi perempuan yang melahirkannya (meskipun balas budi tak harus bersama ibu) (Pamuntjak, 2015:119).

Salwa merupakan anak tertua dalam keluarganya, meskipun dari keluarga yang berada tapi kehidupan yang dijalaninya sangatlah sederhana. Setelah beranjak dewasa, ia memutuskan untuk merantau melanjutkan kuliahnya. Akhirnya, dia diterima sebagai dosen di UGM sesuai cita-citanya. Setelah mendapat pekerjaan, ia tak lupa mengirim uang untuk keluarganya. Ia merasa punya tanggung jawab untuk keluarganya meskipun yang dikirimnya tidak seberapa. Hal itu sebagai tanda sebagai baktinya, meskipun tak sebanding dengan pengorbanan ibu. Aspek psikis superego yang ditunjukan Salwa ini tercermin dari perilakunya yang mulia dan bertanggung jawab. Aspek psikis superego yang dimiliki Salwa membuatnya kuat untuk menjadi anak yang berbakti kepada orang tuanya.

\section{Simpulan}

Berangkat dari pembahasan tersebut, maka bagian ini menyimpulan id, ego, dan superego tokoh?tokoh dalam novel Amba Karya Laksmi Pamuntjak. Aspek psikis id dalam novel Amba karya Laksmi Pamuntjak dapat terlihat dari keinginan Amba, Bhisma, dan Salwa akan kebutuhan seksualitas. Mereka membutuhkan cinta dan kasih sayang. Aspek psikis ego dalam novel Amba dapat dilihat dari dorongan ego Amba yang mencintai Bhisma dengan tulus, sehingga menyusul Bhisma ke pulau Buru. Dorongan ego Salwa yang mencari kabar tentang Amba dan kejelasan hubungannya dengan Amba, sehingga dia tahu bahwa Amba telah mengkhianatinya. Aspek psikis superego dalam novel Amba dapat dilihat dari superego Amba yang sadar dalam kehidupan hendaknya selalu menjaga perilaku baik itu ucapan dan tindakan. Superego Bhisma terlihat dengan menghargai dan menghormati serta keberaniannya untuk memberikan pemahaman yang benar. Superego Salwa terlihat dengan sikap tanggung jawab, berbakti dan menghargai nasihat-nasihat yang diberikan kepadanya.

\section{Ucapan Terima Kasih}

Tulisan ini berasal dari penelitian yang dibimbing oleh Prof. Dr. Herman J. Waluyo dan Prof. Suyitno untuk itu ucapan terima kasih diberikan kepada dua pembimbing tersebut. Terima kasih juga diberikan kepada Pimpinan dan Staf Pascasarjana Pendidikan Bahasa Indonesia, Universitas Sebelas Maret yang menfasilitasi penelitian ini. 


\section{Daftar Rujukan}

Eagleton, Terry. 2010. Teori Sastra Sebuah Pengantar Komprehensif. Yogyakarta : Jalasutra, 2010. Pamuntjak, Laksmi. 2012. Amba. Jakarta : Gramedia Pustaka, 2012.

Minderop, Albertine. Psikologi Sastra: Karya Sastra, Metode, Teori, Dan Contoh Kasus. Jakarta: Yayasan Pustaka Obor Indonesia, 2011.

Minderop, Albertine. Metode Karakterisasi Telaah Fiksi. Jakarta: Yayasan Obor Indonesia, 2005.

Nurgiyantoro.cTeori Pengkajian Fiksi. Yogyakarta:GMUP, 2009. 